\title{
Penggunaan Media Film Animasi Untuk Meningkatkan Keterampilan Berbicara Melaporkan Pada Siswa Kelas XI IPS 1 SMAN 1 Bayan Kabupaten Lombok Utara
}

\author{
Ramlah $^{1}$, Nurdin ${ }^{2}$ \\ Universtias Terbuka
}

\begin{abstract}
Abstrak. Penelitian ini bertujuan untuk meningkatkan kemampuan berbicara khususnya kemampuan berbicara melaporkan dengan media pembelajaran film animasi pada kelas XI IPS 1 SMAN 1 Bayan Kabupaten Lombok Utara pada semester Ganjil Tahun Pembelajaran 2017-2018 dengan jumlah siswa sebanyak 22 orang. Penelitian difokuskan pada peningkatan aspek-aspek berbicara baik faktor kebahasaan maupun non kebahasaan dalam proses pembelajaran. Objek penelitian ini adalah peningkatan kemampuan berbicara melaporkan dalam interaksi pembelajaran. Penelitian ini merupakan penelitian tindakan kelas. Pengumpulan data dilakukan dengan tes berbicara. Instrumen penelitian yang digunakan adalah tes berbicara. Penelitian ini menggunakan teknik analisis deskriptif kualitatif yang didukung oleh data kuantitatif. Keabsahan data diperoleh melalui validitas hasil, dan validitas proses. Berdasarkan hasil penelitian, kemampuan siswa dalam hal berbicara melaporkan setelah dilakukan implementasi tindakan dengan media film animasi mengalami peningkatan. Peningkatan tersebut dapat diketahui dari indikator keberhasilan proses dan indikator keberhasilan hasil. Keberhasilan pembelajaran dapat dilihat dari perubahan keadaan siswa yang pasif, lebih banyak diam, dan tidak terlalu memperhatikan pelajaran menjadi lebih aktif dan antusias selama mengikuti pembelajaran. Suasana pembelajaran pun menjadi lebih hidup dan menyenangkan setelah melihat film. Selain itu, ketika tes dilaksanakan, terlihat kemampuan berbicara dan kepercayaan diri siswa meningkat secara bertahap dari tiap siklus yang dilakukan. Hasil skor penilaian tersebut menunjukkan terjadi peningkatan pada aspek-aspek kemampuan berbicara, yaitu pada pra siklus sebesar 41 meningkat menjadi 59 pada siklus I. Hasil penilaian siklus I menuju siklus II mengalami peningkatan dari 59 menjadi 72. Jadi, dapat disimpulkan bahwa setelah dilakukan implementasi tindakan dengan media film animasi, kemampuan siswa dalam hal berbicara melaporkan mengalami peningkatan secara bertahap dari setiap siklus. Penggunaan metode pembelajaran ini dapat membantu siswa agar berani mengeluarkan pendapat dan ide/gagasan secara lebih lancar dan lebih runtut. Selanjutnya, siswa dapat meningkatkan sikap berpikir yang kritis, logis, sistematis, dan lebih mandiri.
\end{abstract}

\section{Kata Kunci: Media Film Animasi, Keterampilan Berbicara}

\section{PENDAHULUAN}

Latar Belakang

Pembelajaran bahasa Indonesia diarahkan untuk meningkatkan kompetensi berbahasa Indonesia bagi peserta didik. Tujuan utama pembelajaran bahasa Indonesia adalah agar peserta didik mampu berkomunikasi dengan baik dan benar di dalam kehidupannya seharihari baik di lingkungan formal maupun di lingkungan non formal. Berbicara merupakan aktivitas penting dalam kehidupan, karena dengan berbicara kita dapat berkomunikasi dengan orang lain. Menurut Arsyad dan Mukti (1991:15) keterampilan berbicara dipengaruhi oleh dua faktor, yaitu eksternal dan internal. Menurut Tarigan (1981:16) tujuan berbicara ada tiga, yaitu: memberitahukan, melaporkan (toinform), (2) menjamu, menghibur (toentertain), dan (3) membujuk, mengajak, mendesak, dan 
meyakinkan (to persuade). Singkatnya, semua orang yang berkomunikasi perlu memiliki keterampilan berbicara yang baik, terlebih seorang pelajar dan pengajar, agar proses belajar mengajar bisa berjalan dengan lancar. Temuan awal pada pembelajaran berbicara pada siswa kelas XI SMA N 1 Bayan, bahwa kemampuan berbicara siswa melaporkannya masih kurang. Agar pembelajaran berjalan optimal seorang guru harus bisa menentukan model pembelajaran yang cocok sesuai dengan realitas dan kondisi sekolah tersebut. Model pembelajaran berbicara dengan media film animasi adalah suatu model pembelajaran yang baik dalam upaya menfasilitasi peserta didik untuk mengembangkan kemampuan berbicaranya melalui media film.

Identifikasi Masalah, berdasarkan latar belakang masalah yang telah diungkapkan di atas, dapat diidentifikasikan beberapa masalah yang terjadi di dalam pembelajaran berbicara anatara lain: a. kurangnya model pembelajaran dalam pengajaran keterampilan berbicara. b. kurangnya keberanian dan kepercayaan diri siswa dalam mengungkapkan ide-ide atau pendapatnya di depan umum. c. siswa ketika berbicara lebih banyak tidak fokus dengan topik pembeicaraan di dalam pembelajaran. d. rendahnya kemampuan siswa untuk berbicara dimuka umum terutama berbicara melaporkan.

Batasan Masalah, penelitian ini berfokus pada peningkatan kemampuan berbicara siswa dengan media film animasi pada kelas XI SMAN1 Bayan Kabupaten Lombok Utara.

Rumusan Masalah sebagai berikut: a. bagaimana upaya peningkatan kemampuan berbicara melaporkan melalui media film animasi?, b. seberapa besar peningkatan kemampuan berbicara melaporkan melalui media film animasi?
Tujuan Penelitian adalah untuk meningkatkan pemebelajaran keterampilan berbicara bahasa Indonesia. Sedangkan, tujuan khusus sebagai berikut: a. mengetahui upaya peningkatan kemampuan berbicara melalui media film animasi. b. mengetahui seberapa besar peningkatan kemampuan berbicara melalui media film animasi.

Manfaat Teoritis penelitian ini diharapkan dapat memberikan sumbangan bagi perkembangan keilmuan dan pengajaran kemampuan berbahasa, khususnya dalam pembelajaran keterampilan berbicara melaporkan. Selain itu, penelitian ini diharapkan dapat memberikan sumbangan dalam pengembangan teknik pembelajaran menjadi lebih variatif.

Manfaat Praktis yaitu, a. siswa diharapkan dapat terpacu untuk meningkatkan prestasi akademiknya dengan belajar melalui media film animasi dan menjadikan siswa kritis terhadap hasil karya belajarnya, b. peneliti, memperoleh pengalaman dan pengetahuan dalam menerapkan model pembelajaran dengan media film animasi.c. guru bahasa Indonesia, memperoleh tambahan pengetahuan dan wawasan tentang model pembelajaran khususnya pembelajaran keterampilan berbicara, d. bagi sekolah, diharapkan dapat digunakan sebagai acuan untuk meningkatkan prestasi siswa dengan pengadaan media yang bervariasise hingga minat belajar siswa meningkat.

Batasan Istilah dalam penelitian dimaksudkan untuk memberikan gambaran istilah-istilah yang terdapat di dalam penelitian, sebagai berikut: a. peningkatan diartikan sebagai suatu perubahan dari keadaan kurang baik menjadi keadaan yang lebih baik, b. kemampuan berbicara melaporkan adalah kemampuan untuk melaporkan secara lisan yang bersifat informativ. 


\section{KAJIAN PUSTAKA}

\section{A. Hakekat Berbicara}

Menurut Tarigan (1981:15) berbicara adalah kemampuan mengucapkan bunyi-bunyi artikulasi atau kata-kata untuk mengekspresikan, menyatakan serta menyampaikan pikiran, gagasan, dan perasaan. Senada dengan Tarigan, Hurlock (1991:176) menyatakan, bahwa berbicara merupakan bentuk bahasa yang menggunakan artikulasi atau kata-kata yang digunakan untuk menyampaikan maksud. Hakikat berbicara yang dikemukakan Nurgiyantoro (1995:274) adalah aktivitas berbahasa kedua yang dilakukan manusia dalam kehidupan berbahasa, yaitu: setelah aktivitas mendengarkan.

Berbicara untuk melaporkan merupakan salah satu ragam seni berbicara di depan umum. Seperti yang diungkapkan oleh Tarigan (1981:22-23) seni berbicara dapat dibagi dalam dua kategori, yaitu: berbicara di depan umum dan berbicara pada konferensi.

\section{B. Tujuan Berbicara}

Menurut Tarigan (1981:15) tujuan utama dari berbicara adalah berkomunikasi. Agar dapat menyampaikan pikiran secara efektif maka pembicara harus memahami makna permasalahan yang akan disampaikan. Tujuan berbicara yang diungkapkanTarigan (1981:16), sebagai berikut: memberitahukan, melaporkan menghibur, membujuk, mengajak, mendesak, meyakinkan, menstimulasi pendengar, menggerakkan pendengar.

\section{Faktor-Faktor Keefektifan Berbicara}

Menurut Arsyad dan Mukti (1991:17) keefektifan komunikasi dipengaruhi oleh kemampuan berbicara seseorang. Agar dapat menyampaikan informasi dengan efektif dan efisien, sebaiknya pembicara memahami betul-betul isi pembicaraan. Selain itu, seseorang juga harus mampu mengevaluasi efek komunikasi terhadap pendengar. Jadi, bukan hanya apa yang didengar tetapi juga bagaimana mengemukakannya.

Menurut Arsjad dan Mukti (1991:17-22) terdapat dua faktor yang harus diperhatikan pembicara agar dapat berbicara secara efektif dan efisien, yaitu faktor kebahasaan dan faktor non kebahasaan. Faktor-Faktor Kebahasaan yaitu: a. ketepatan ucapan, b. penempatan ekanan, nada, sendi, durasi yang sesuai, c. pilihan kata, d. ketepatan sasaran pembicaraan. Faktor-aktor non kebahasaan yaitu: a. sikap wajar, tenang, dan tidak kaku, b. pandangan harus diarahkan kepada lawan bicara, c. kesediaan menghargai pendapat orang lain, d. gerak-gerik dan mimik yang tepat, e. kenyaringan suara, f. kelancaran, g. relevansi/penalaran, h. penguasaan topik.

D. Media Pembelajaran

Menurut Soeparno (1998:1) media adalah suatu alat yang dipakai sebagai suatu saluran untuk menyampaikan suatu pesan dari sumber kepada penerima (receiver).

Menurut Sudjana dan Rivai (dalam Arsyad, 2002:24) terdapat beberapa manfaat media pembelajaran: a. pembelajaran akan lebih menarik, b. bahan pembelajaran akan menjadi lebih jelas, c. metode belajar akan lebih bervariasi, d. siswa dapat lebih banyak melakukan kegiatan belajar.

Kriteria pemilihan media pembelajaran menurut Zulkarnaen (melalui Sadiman, 2002: 22) mengemukakan enam prinsip pemilihan media seperti berikut ini: a. tujuan, b. ketepatgunaan, c. keadaan siswa, d. ketersediaan, e. mutu teknis, f. biaya.

Klasifikasi media pembelajaran menurut Hamzah (1985:22), media pendidikan dapat diklasifikasikan seperti berikut ini: a. Media audio, yaitu alat yang dapat menghasilkan bunyi seperti tape recorder dan radio, $b$. media visual, yaitu media yang dapat memperlihatkan bentuk dan rupa yang dikenal sebagai alat peraga. 
Media film itu bergerak dari frame ke frame di depan lensa pada layar, gambar-gambar itu juga secara cepat bergantian dan memberikan proses visual yang kontinyu di antara gambar demi gambar tak ada celah- celah, bergerak dengan cepat dan pada layar terlihat gambargambar yang berurutan dan melukiskan suatu peristiwa, cerita-cerita, benda-benda, dan murni seperti pada aslinya (Hamalik, 1980:84).

Media film animasi, kata animasi berasal dari kata "anima" yang berarti jiwa (soul) atau nafas kehidupan. Animasi berasal dari semua penciptaan kehidupan baik dalam objek mati maupun ke dalam objek yang tidak bernyawa (Harry, 1991:2). Menurut Departemen Pendidikan Nasional dalam Kamus Besar Bahasa Indonesia (2005:53) animasi adalah acara televisi yang berbentuk rangkaian tulisan atau gambar yang digerakkan secara mekanis elektronis sehingga tampak di layar menjadi gerak.

E. Kerangka Berpikir

Pembelajaran keterampilan berbicara merupakan salah satu bagian dari pembelajaran berbahasa sebagai upaya untuk meningkatkan kemampuan verbal siswa. Mengingat pentingnya kedudukan pengajaran bahasa bagi dunia pendidikan, pengajaran ini diberikan sejak siswa sekolah dasar. Pembelajaran bahasa di sekolah mempunyai konsep sederhana, yaitu pembelajaran yang sedapat mungkin menarik perhatian siswa untuk lebih senang dalam mempelajari bahasa dan mengapresiasikannya. Pemilihan film animasi ini tentu saja disesuaikan dengan usia peserta didik dan memiliki nilai-nilai pendidikan di dalamnya.

\section{F. Hipotesis Tindakan}

Berdasarkan landasan teori dan kerangka berpikir yang telah diuraikan di atas, hipotesis penelitian ini adalah pembelajaran keterampilan berbicara dengan media film animasi dapat meningkatkan kemampuan berbicara.

\section{METODE PENELITIAN}

\section{A. Setting Penelitian}

Peneltian ini akan diaksanakan di kelas XI IPS 1 SMA Negeri 1 Bayan Kabupaten Lombok Utara Provinsi Nusa Tenggara Barat. Kelas yang dipilih berdasarkan hasil pengamatan peneliti selaku guru atau pendidik selama proses pembelajaran berlangsung. Berdasarkan survei terkait rendahnya kemampuan berbicara siswa di depan umum dan kurang bervariasinya metode pembelajaran keterampilan berbicara di sekolah tersebut. Subjek penelitian ini adalah kelas XI IPS 1 SMAN 1 Bayan pada semester ganjil Tahun Pembelajaran 20172018 dengan jumlah siswa sebanyak 22. Objek penelitian ini adalah peningkatan kemampuan berbicara melaporkan di depan kelas. Waktu yang dimanfaatkan untuk melakukan penelitian ini adalah bulan September-November 2018. Penelitian dilakukan sebanyak 2 siklus.

\section{B. Jenis Penelitian}

Penelitian ini merupakan penelitian tindakan kelas (Action Research Class). Penelitian ini dilakukan secara kolaboratif dan partisipatif bekerja sama dengan guru bahasa Indonesia kelas XI IPS 1 SMAN 1 Bayan Kabupaten Lombok Utara, yaitu Bapak Bukran, S.Pd., M.Pd. Penelitian tindakan kelas adalah penelitian yang dilakukan guru kelas atau di sekolah tempat guru pendamping mengajar dengan penekanan pada penyempurnaan atau peningkatan proses dan praktik pembelajaran (Arikunto, 2006: 96).

\section{Prosedur Penelitian}

Menurut Kemmis dan Mc. Teggart (2009) mengemukakan bahwa konsep pokok penelitian tindakan kelas terdiri dari 4 komponen yaitu perencanaan, pelaksanaan tindakan, pengamatan, dan refleksi. 


\section{Teknik Pengumpulan Data}

Pengumpulan data menggunakan teknik pengamatan pada saat siswa berbicara melaporkan. Tes berbicara digunakan untuk mengukur kemampuan berbicara melaporkan dengan praktik berbicara secara individual berdasarkan aspek-aspek penilaian yang telah disusun.

\section{E. Instrumen Penelitian}

Instrumen penelitian adalah tes berbicara untuk mengukur kemampuan berbicara melaporkan siswa. Tes ini disusun berdasarkan teori Arsjad dan Mukti (199: 1722) dengan kriteria seperti: ketepatan ucapan (lafal), penempatan tekanan, nada, jeda, dan durasi, pemilihan diksi, ketepatan sasaran pembicaraan dan kesediaan menghargai pendapat orang lain, sikap wajar, tenang, dan tidak kaku, gerak-gerik, mimik yang tepat, dan pandangan mata, kelancaran, kenyaringan suara, relevansi/penalaran, kreativitas, dan keruntutan, penguasaan topik.

\section{F. Teknik Analisis Data}

Menurut Sumadi (dalam Bukran 2015: 4748) mengatakan bahwa menganalisis data merupakan suatu langkah yang sangat kritis dalam penelitian. Data yang terkumpul harus dilakukan penyeleksian atas dasar reliabilitas dan validitasnya. Penelitian ini menggunakan teknik analisis data kualitatif dan teknik kuantitatif, yaitu mendeskripsikan keterampilan berbicara melaporkan sebelum dan sesudah implementasi tindakan dilakukan.

\section{G. Validasi Data}

Borgdn Gall (dalamWiriaatmaja, 2005:164), menyatakan ada lima tahap kriteria validitas, yaitu validitas hasil, validitas proses, validitas demokratis, validitas katalik, dan validitas dialog. Dalam penelitian ini hanya 3 yaitu: validitas hasil, validitas proses, dan validitas demokratis.

\section{H. Indikator Keberhasilan}

Indikator keberhasilan proses dilihat dari perkembangan proses selama pembelajaran. Indikator keberhasilan produk didasarkan pada perubahan hasil belajar siswa yang positif baik secara perseorangan atau keseluruhan. Dalam indikator keberhasilan produk ini terdapat sepuluh aspek yang dinilai berdasarkan teori Arsjad dan Mukti (199: 1722).

\section{HASIL DAN PEMBAHASAN}

Hasil penelitian berikut pembahasan dari pembelajaran dengan media film animasi di kelas XI IPS 1 SMAN 1 Bayan Kabupaten Lombok Utara Nusa Tenggara Barat menyajikan data-data yang kemudian dianalisis sesuai dengan teori yang digunakan. Hasil penelitian dideskripsikan secara rinci berdasar pada perencanaan, pelaksanaan, pengamatan, dan refleksi. Kriteria keberhasilan praktek berbicara menggunakan media pembelajaran film animasi adalah terdapat peningkatan yang berkaitan dengan keterampilan berbicara khususnya berbicara untuk melaporkan. Hal tersebut ditunjukkan dengan peningkatan skala penilaian dari tiap perlakuan yang dilakukan kearah yang lebih baik. Selain itu, indikator keberhasilan dilihat dari indicator keberhasilan proses, yaitu adanya peningkatan keaktifan siswa dalam berbicara. Sedangkan, untuk mengetahui tingkat kemampuan berbicara siswa sebelum implementasi tindakan maka terlebih dahulu dilakukan tes pra siklus.

\subsection{Hasil Penelitian Pra Siklus}

Tingkat kemampuan berbicara siswa pada pra siklus adalah rata-rata, 41 tergolong cukup. Dapat dilihat dari sebaran berikut ini: a. Ketepatan ucapan (lafal) skor yang diperoleh adalah 41 tergolong cukup, b. penempatan tekanan, nada, jeda, dan durasi skor yang diperoleh adalah 42 tergolong cukup. c. pemilihan diksi, skor yang diperoleh adalah 40 tergolong sangat kurang. d. 
ketepatan sasaran pembicaraan dan menghargai pendapat orang lain skor yang diperoleh adalah 43 tergolong cukup. e. sikap wajar, tenang, dan tidak kaku, skor yang diperoleh adalah 40 tergolong sangat kurang. f. gerak-gerik, mimik yang tepat, dan pandangan mata, skor yang diperoleh adalah 42 tergolong cukup. g. kelancaran, skor yang diperoleh adalah 41 tergolong cukup. $h$. kenyaringan suara, skor yang diperoleh adalah 43 tergolong cukup. i. relevansi/penalaran, kreativitas, dan keruntutan, skor yang diperoleh adalah 42 tergolong cukup. j. penguasaan topik, skor yang diperoleh adalah 43 tergolong cukup.

4.2 Pelaksanaan Pembelajaran dengan Media Film Animasi (Siklus I)

\section{a. Perencanaan (Planning)}

Pada tahap ini, merencanakan prosedur tindakan yang akan dilakukan untuk meningkatkan keterampilan berbicara siswa. Perencanaan ini dimulai dengan perencanaan strategi pembelajaran, pengorganisasian kelas dan waktu, evaluasi, dan dokumentasi. Selanjutnya, diadakan penyamaan persepsi dan berdiskusi untuk mengidentifikasi permasalahan yang muncul dalam pembelajaran berbicara sekaligus menemukan solusi atas masalah tersebut.

\section{b.Tindakan}

Tindakan pada siklus I dilakukan 80 menit. Pada tahap ini, menetapkan tindakan sesuai perencanaan yang telah dilakukan untuk meningkatkan keterampilan subjek. Pada pertemuan ini guru menjelaskan tentang prinsip model pembelajaran berbicara dengan media film animasi sekaligus materi tentang keterampilan berbicara yang harus dikuasai siswa sesuai dengan RPP dan silabus. Dalam pembelajaran tersebut guru menanyakan pada siswa mengenai kesulitan-kesulitan apa yang sering dialami siswa ketika berbicara. Hal ini penting dilakukan sebagai salah satu cara membantu siswa menemukan inti permasalahan yang dihadapi.

Pada kesempatan ini, guru memancing para siswa dengan pertanyaan-pertanyaan seperti: apakah kalian merasa grogi untuk mengungkapkan pendapat? apakah kalian sering merasa takut salah ketika akan mengungkapkan ide-ide? apa yang kalian rasakan ketika kalian maju di depan kelas untuk menyampaikan suatu hal?. Pembelajaran dilanjutkan dengan pemberian materi yang berkaitan dengan pembelajaran berbicara dengan menggunakan media film animasi. Guru memberikan materi tentang hal-hal yang harus dikuasai oleh siswa ketika melakukan praktik berbicara khususnya berbicara melaporkan. Pembelajaran pertemuan ini dilanjutkan dengan menonton film animasi selama15-20 menit. Selama pembelajaran berlangsung peneliti dan kolaborator mengamati perilaku siswa, reaksi, metode, dan suasana pembelajaran tersebut. Pembelajarn diakhiri dengan memberikan kesimpulan tentang pembelajaran berbicara melaporkan.

\subsection{Hasil Penelitian Siklus I}

Rata-rata tingkat kemampuan berbicara siswa pada siklus I adalah 59 tergolong cukup. Dapat dilihat dari sebaran berikut ini: a. Ketepatan ucapan (lafal) skor yang diperoleh adalah 62 tergolong baik, b. penempatan tekanan, nada, jeda, dan durasi skor yang diperoleh adalah 59 tergolong cukup. c. pemilihan diksi, skor yang diperoleh adalah 60 tergolong cukup. d. ketepatan sasaran pembicaraan dan menghargai pendapat orang lain skor yang diperoleh adalah 61 tergolong baik. e. sikap wajar, tenang, dan tidak kaku, skor yang diperoleh adalah 58 tergolong cukup. f. gerak-gerik, mimik yang tepat, dan pandangan mata, skor yang diperoleh adalah 59 tergolong cukup. g. kelancaran, skor yang diperoleh adalah 57 tergolong cukup. $h$. kenyaringan suara, skor yang diperoleh 
adalah 58 tergolong cukup. i. relevansi/penalaran, kreativitas, dan keruntutan, skor yang diperoleh adalah 58 tergolong cukup. j. penguasaan topik, skor yang diperoleh adalah 58 tergolong cukup.

4.4 Hasil tes pra siklus dibandingkan dengan hasil tes siklus I

Hasil perbandingan terdapat peningkatan kemampuan berbicara sebesar 18 poin. Aspek-aspek tersebut antara lain: 1. aspek ketepatan ucapan (lafal) sebesar 21 poin, 2. aspek penempatan tekanan, nada, jeda, dan durasi sebesar 17 poin, 3. aspek pemilihan diksi sebesar 20 poin, 4. Aspek ketepatan sasaran pembicaraan dan kesediaan menghargai pendapat orang lain sebesar 18 poin, 5. Aspek sikap wajar, tenang, dan tidak kaku sebesar 18 poin, 6. aspek gerak-gerik, mimik yang tepat, dan pandangan mata sebesar 17 poin, 7. aspek kelancaran sebesar 16 poin, 8. Aspek kenyaringan suara sebesar 15 poin, 9. aspek relevansi/penalaran, kreatifitas, dan keruntutan sebesar 16 poin, dan 10. aspek penguasaan topik sebesar 15 poin.

Dengan demikian, dapat disimpulkan bahwa kemampuan berbicara siswa kelas XI IPS 1 khususnya dalam hal melaporkan setelah dilakukan tindakan siklus I mengalami peningkatan sebesar 18 poin tapi masih rendah, oleh karena itu perlu diadakan tindakan siklus II.

\subsection{Hasil Penelitian Siklus II}

\section{a. Perencanaan (Planning)}

Pada tahap ini, peneliti dan kolaborator merencanakan prosedur tindakan yang akan dilakukan untuk meningkatkan keterampilan berbicara siswa. Perencanaan ini dimulai dengan perencanaan strategi pembelajaran, pengorganisasian kelas dan waktu, evaluasi, dan dokumentasi. Selanjutnya, peneliti dan kolaborator menyamakan persepsi dan berdiskusi untuk mengidentifikasi permasalahan yang muncul dalam pembelajaran berbicara sekaligus menemukan solusi atas masalah tersebut. Peneliti dan guru sebagai kolaborator juga menyiapkan skenario pembelajaran dan menyusun tes akhir siklus II.

\section{b.Tindakan}

Tindakan pada siklus II dilakukan 80 menit. Pada tahap ini, peneliti dan kolaborator menetapkan tindakan sesuai perencanaan yang telah dilakukan untuk meningkatkan keterampilan subjek. Pada pertemuan ini guru menjelaskan tentang prinsip model pembelajaran berbicara dengan media film animasi sekaligus materi tentang keterampilan berbicara yang harus dikuasai siswa sesuai dengan RPP dan silabus. Dalam pembelajaran tersebut guru menanyakan pada siswa mengenai kesulitan-kesulitan apa yang sering dialami siswa ketika berbicara. Hal ini penting dilakukan sebagai salah satu cara membantu siswa menemukan inti permasalahan yang dihadapi.

Pada kesempatan ini, guru memancing para siswa dengan pertanyaan-pertanyaan seperti: apakah kalian merasa grogi untuk mengungkapkan pendapat? apakah kalian sering merasa takut salah ketika akan mengungkapkan ide-ide? apa yang kalian rasakan ketika kalian maju di depan kelas untuk menyampaikan suatu hal?. Pembelajaran dilanjutkan dengan pemberian materi yang berkaitan dengan pembelajaran berbicara dengan menggunakan media film animasi. Guru memberikan materi tentang hal-hal yang harus dikuasai oleh siswa ketika melakukan praktik berbicara khususnya berbicara melaporkan. Pembelajaran pertemuan ini dilanjutkan dengan menonton film animasi selama 15-20 menit. Selama pembelajaran berlangsung peneliti dan kolaborator mengamati perilaku siswa, reaksi, metode, dan suasana pembelajaran tersebut. Pembelajarn diakhiri dengan memberikan 
kesimpulan tentang pembelajaran berbicara melaporkan.

4.6 Hasil Penelitian Siklus II

Tingkat kemampuan berbicara siswa diukur dengan tindakan siklus II. Rata-rata tingkat kemampuan berbicara siswa pada siklus I adalah 72 tergolong baik. Dapat dilihat dari sebaran berikut ini: a. Ketepatan ucapan (lafal) skor yang diperoleh adalah 73 tergolong baik, b. penempatan tekanan, nada, jeda, dan durasi skor yang diperoleh adalah 77 tergolong baik. c. pemilihan diksi, skor yang diperoleh adalah 71 tergolong baik. d. ketepatan sasaran pembicaraan dan menghargai pendapat orang lain skor yang diperoleh adalah 70 tergolong baik. e. sikap wajar, tenang, dan tidak kaku, skor yang diperoleh adalah 71 tergolong baik. f. gerakgerik, mimik yang tepat, dan pandangan mata, skor yang diperoleh adalah 72 tergolong baik. g. kelancaran, skor yang diperoleh adalah 71 tergolong baik. h. kenyaringan suara, skor yang diperoleh adalah 73 tergolong baik. i. relevansi/penalaran, kreativitas, dan keruntutan, skor yang diperoleh adalah 70 tergolong baik. j. penguasaan topik, skor yang diperoleh adalah 72 tergolong baik.

4.7 Hasil tes siklus I dibandingkan dengan hasil tes siklus II

Hasil perbandingan terdapat peningkatan kemampuan berbicara sebesar 18 poin. Aspek-aspek tersebut antara lain: 1. aspek ketepatan ucapan (lafal) sebesar 11 poin, 2. aspek penempatan tekanan, nada, jeda, dan durasi sebesar 18 poin, 3. aspek pemilihan diksi sebesar 11 poin, 4. Aspek ketepatan sasaran pembicaraan dan kesediaan menghargai pendapat orang lain sebesar 11 poin, 5. Aspek sikap wajar, tenang, dan tidak kaku sebesar 13 poin, 6. aspek gerak-gerik, mimik yang tepat, dan pandangan mata sebesar 13 poin, 7. aspek kelancaran sebesar 1314 poin, 8. Aspek kenyaringan suara sebesar 15 poin, 9. aspek relevansi/penalaran, kreatifitas, dan keruntutan sebesar 12 poin, dan 10. aspek penguasaan topik sebesar 14 poin.

Dengan demikian, dapat disimpulkan bahwa kemampuan berbicara siswa kelas XI IPS 1 SMA N I Bayan Lombok Utara dalam hal berbicara melaporkan setelah dilakukan tindakan siklus II mengalami peningkatan sebesar 18 poin, oleh karena itu tidak perlu diadakan tindakan siklus berikutnya.

\section{A. Kesimpulan}

Kesimpulan hasil penelitian ini mencakup dua hal, yaitu upaya peningkatan kemampuan berbicara melaporkan melalui media film animasi dan seberapa besar peningkatan kemampuan berbicara melaporkan melalui media film animasi pada siswa kelas XI IPS1 SMAN 1 Bayan Kabupaten Lombok Utara.

Hasil penelitian menunjukkan bahwa pembelajaran kemampuan berbicara dengan media film animasi dapat meningkatkan kemampuan siswa dalam hal berbicara melaporkan baik pada aspek kebahasaan maupun aspek non kebahasaan. Implementasi tindakan berupa pembelajaran dengan media film animasi ini dilakukan dalam dua siklus dengan tujuan meningkatkan aspek-aspek kemampuan berbicara siswa. Keberhasilan ini dapat dilihat dari indicator keberhasilan proses dan keberhasilan hasil. Keberhasilan proses dilihat dari perubahan sikap dan perilaku siswa kearah yang lebih baik seperti keadaan siswa yang menjadi lebih aktif dan antusias selama mengikuti pembelajaran. Kegiatan pembelajaran pun suasananya menjadi kondusif, lebih hidup, dan lebih menyenangkan. Selain itu, siswa terlihat lebih percaya diri dalam mengungkapkan gagasan dan pikirannya. Penggunaan metode pembelajaran ini dapat membantu siswa agar berani mengeluarkan pendapat dan ide/gagasannya secara lebih lancer dan lebih runtut. Selanjutnya, siswa dapat meningkatkan sikap berpikir yang kritis, 
logis, sistematis, dan lebih mandiri. Berdasarkan skor hasil penilaian, kemampuan berbicara siswa mengalami peningkatan pada tiap aspek penilaian berbicara selama proses pembelajaran berlangsung. Skor kumulatif siswa ketika pra siklus sebesar 41 meningkat menjadi 59 pada siklus I, dan meningkat menjadi 72 pada siklus II.

D. Saran

Diharapkan guru dapat melanjutkan dan mengembangkanmodel pembelajaran dengan media film animasi dalam proses pembelajaran selanjutnya guna mengoptimalkan hasil pembelajaran.

\section{DAFTARPUSTAKA}

Arikunto, Suharsimi. 2006. Prosedur Penelitian Suatu Pendekatan Praktik. Jakarta: Rineka Cipta.

Aqib, Zainal, dkk. 2009. Penelitian Tindakan Kelas. Bandung: CV. Yrama Widya.

Arsyad, Azhar. 2002. Media Pembelajaran. Jakarta: Raja Grafindo Persada.

Arsjad, Maidar \&Mukti, U.S. 1991. Pembinaan Kemampuan Berbicara Bahasa Indonesia. Jakarta: Erlangga

Departemen Pendidikan Nasional. 2005. Kamus Besar Bahasa Indonesia. Jakarta: Balai Pustaka.

Hamalik, Oemar. 1980. Media Pendidikan. Bandung: Alumni.

Hamzah, Suleman, Amir. 1985. Media Audio Visual untuk Pengajaran Penerangan dan Penyuluhan. Jakarta: Gramedia pustaka Utama.

Harry, Herman. 1991. Animasi. Yogyakarta: Multi Media Training Center. Hurlock, Elizabet, B. 1991. Perkembangan Anak. Jakarta: Erlangga.

Madya, Suwarsih. 1994. Panduan Penelitian Tindakan. Yogyakarta: Panduan Penelitian IKIP Yogyakarta.
Nurgiyantoro, Burhan. 1995. Penilaian dalam Pengajaran Bahasa dan Sastra. Yogyakarta: BPFE.

2002. Statistik Terapanuntuk Penelitian Ilmu-Ilmu Sosial. Yogyakarta: Gajah Mada University Press.

Priggawidagda, Suwarna. 2002. Strategi Penguasaan Berbahasa. Yogyakarta: Adicita Karya Nusa.

Rusman. 2012. Model-Model Pembelajaran : Mengembangkan Profesionalisme Guru. Jakarta : Raja Grafindo Persada. Sadiman, dkk. 2002. Media Pendidikan Pengertian Pengembangan dan Pemanfaatannya. Jakarta: Raja Grafindo Persada.

Soeparno.1988. Media Pengajaran Bahasa. Klaten: Intan Pariwara.

Suyatno. 2004. Teknik Pembelajaran Bahasa dan Sastra. Jakarta: penerbit SIC.

Tarigan, Henri Guntur. 1981. Berbicara Sebagai Salah Satu Aspek Keterampilan Berbahasa. Bandung: Angkasa.

Wiriaatmaja,Rochiati.2005.

MetodePenelitianTindakankelasuntukMening katkanKinerja Guru danDosen. Bandung: Rosda. 